\title{
Effect of Sintering Temperature and Aluminum Concentration on the Hardness, Microstructure and Density of Copper-Aluminum Alloys
}

\author{
D. Slimani1,2,*, A. Souigat ${ }^{1,3}$, R. Gheriani², O. Bentouila ${ }^{3}$ \\ ${ }^{1}$ Ecole normale supérieure de Ouargla, 30000 Ouargla, Algeria \\ ${ }^{2}$ Lab. Rayonnement et Plasmas et Physique des Surfaces, Univ Ouargla, Fac. des Mathématiques et des Sciences \\ de la Matière, 30000 Ouargla, Algeria \\ ${ }^{3}$ Lab. Développement des Energies Nouvelles et Renouvelables en Zones Aride, Univ Ouargla, Fac. des \\ Mathématiques et des Sciences de la Matière, 30000 Ouargla, Algeria
}

(Received 27 July 2020; revised manuscript received 06 August 2021; published online 20 August 2021)

\begin{abstract}
In recent decades, powder metallurgy technology has advanced considerably and been used to manufacture sintered structural components with extremely high dimensional accuracy and excellent surface finish. This process is based on the compression of a mixture of metal powder and sintering in an oven using controlled temperature and atmosphere. This technology meets copper alloys design with excellent mechanical properties at the lowest cost. This prompted us to study the effect of sintering temperature and aluminum concentration on the hardness, microstructure, and density of copper-aluminum (Cu-Al) alloys prepared by using the powder compaction process. In this work, samples of $\mathrm{Cu}-\mathrm{Al}$ alloy with $5,11,14$, and 18 wt. \% of $\mathrm{Al}$ were prepared by mechanical alloying of elemental powders, followed by consolidation under a pressure of $12.5 \mathrm{MPa}$ and sintering at $700-1000{ }^{\circ} \mathrm{C}$ in vacuum for $90 \mathrm{~min}$. Microstructural constituents were examined using X-ray diffraction. Density and hardness were measured and their changes with the size of the granules and the formed phases were studied. The $\gamma_{2}$ phase samples showed higher hardness.
\end{abstract}

Keywords: $\mathrm{Cu}-\mathrm{Al}$ alloys, X-ray diffraction, Hardness, Granular size, $\gamma_{2}$ phase.

\section{INTRODUCTION}

Copper alloys have high thermal conductivity, wear resistance, corrosion resistance, and good mechanical strength to be widely used in applications of friction materials, grinding tools, structure parts, etc. [1-3]. For example, sintered metal friction materials contain some typical copper matrix, friction modifiers and lubricants to get a high and stable coefficient of friction, low wear loss, and good thermal conductivity under the operating conditions of high temperature, high load, and high speed [4].

Powder compaction technology, which is generally called powder metallurgy (PM), has advanced significantly over the past decades [5-8]. This process can be considered as an alternative, lower cost process compared to other similar metal working technologies and provide cost-effective, but higher quality product [9-11].

In this study, we used the PM process to prepare samples of $\mathrm{Cu}-\mathrm{Al}$ alloys $(5,11,14,18$ wt. \% of $\mathrm{Al}$ ) in order to obtain adequate mechanical properties by optimizing sintering and thermal treatment.

\section{EXPERIMENTAL}

The experiment consists of five consecutive steps (see Fig. 1): powder mass preparation, powder mixing, molding, sintering, and sample characterization. $\mathrm{Cu}$ and $\mathrm{Al}$ powders (99.5 wt. \% purity and about $6-60 \mu \mathrm{m}$ particle size for $\mathrm{Cu}$ and $99.5 \mathrm{wt} \%$ purity and about 10$110 \mu \mathrm{m}$ particle size for $\mathrm{Al}$ ) with a composition of $\mathrm{Cu}$ 5 wt. $\% \mathrm{Al}, \mathrm{Cu}-11$ wt. $\% \mathrm{Al}, \mathrm{Cu}-14$ wt. $\% \mathrm{Al}$, and $\mathrm{Cu}-$ 18 wt. $\% \mathrm{Al}$ were mechanically stirred for $90 \mathrm{~min}$. The alloy powder was first cold compacted at a uniaxial pressure of $12.5 \mathrm{MPa}$ using a manual press.

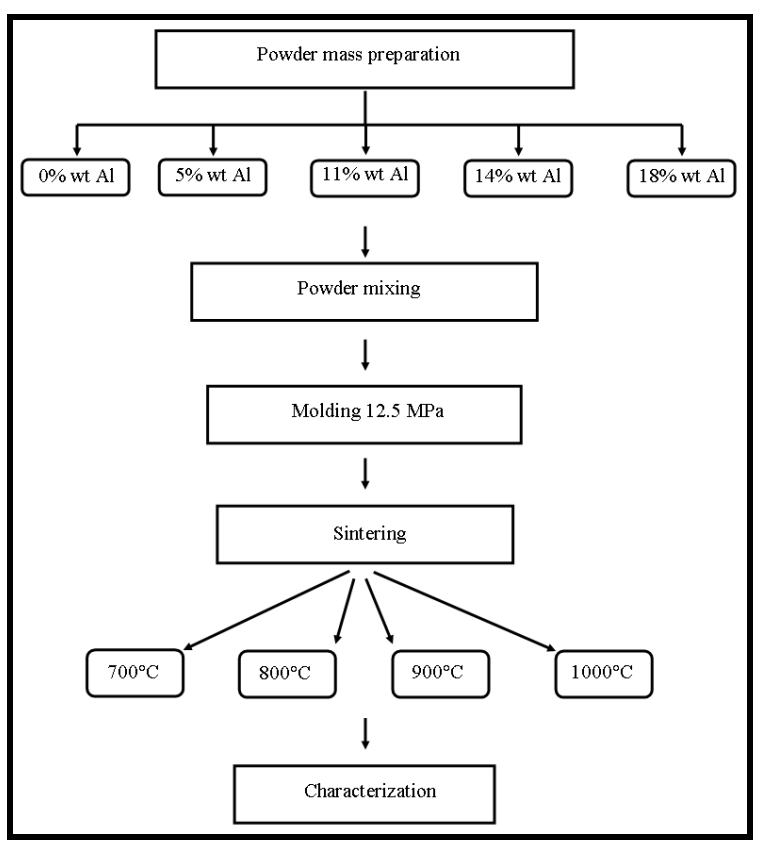

Fig. 1 - Experimental steps

These cold-pressed cylindrical specimens of $20 \mathrm{~mm}$ diameter and $2 \mathrm{~mm}$ height were mounted in ceramic containers. The samples were sintered at 700, 800, 900, and $1000{ }^{\circ} \mathrm{C}$ (Protherm furnaces PTF 14/75/450) in vacuum at $3.5 \times 10^{-3} \mathrm{mbar}$ for $90 \mathrm{~min}$. Cooling was slow inside the oven and faster outside. Phases in the samples were determined by the X-ray diffraction analysis (SEIFERT XRD3003TT) and data base (ICDD/JCPDS PDF Retrievals [Level-1 PDF, Sets 1-51(07)]). The grain sizes

\section{*Slimani.dr@gmail.com}


were determined using XRD spectra. Density was obtained by measuring the mass and size of each sample. The microhardness was measured using a diamond Vickers hardness tester (FM-300e Japan).

\section{RESULTS AND DISCUSSION}

\subsection{XRD Analysis}

Fig. 2, Fig. 3 and Fig. 4 present the X-ray patterns of $\mathrm{Cu}-5$ wt. $\% \mathrm{Al}\left(700,800\right.$, and $\left.900{ }^{\circ} \mathrm{C}\right), \mathrm{Cu}-11$ wt. $\% \mathrm{Al}$ and $\mathrm{Cu}-14$ wt. $\% \mathrm{Al}\left(1000^{\circ} \mathrm{C}\right)$, and $\mathrm{Cu}-18$ wt. $\% \mathrm{Al}$ $\left(800^{\circ} \mathrm{C}\right)$, respectively.

X-ray diffraction patterns of samples with $5 \mathrm{wt}$ \% of $\mathrm{Al}$ show an increase in the $\alpha$ phase with increasing sintering temperature from 700 to $900{ }^{\circ} \mathrm{C}$ (Fig. 2). It seems that the copper network is saturated by aluminum diffusion [12].

Fig. 1 and Fig. 2 show the simulated profiles (solid lines) we have obtained and their comparison with the experimental profiles of phosphorus diffusion in $\mathrm{Ge}$ at the indicated temperatures and times.

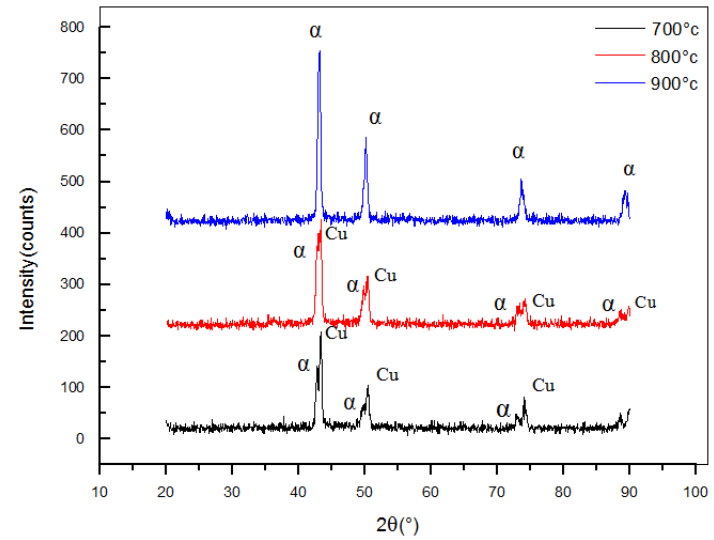

Fig. 2 - X-ray diffraction patterns for $\mathrm{Cu}-5$ wt. $\% \mathrm{Al}(700,800$, and $900{ }^{\circ} \mathrm{C}$ )

X-ray diffraction patterns of samples with 11 wt. \% of $\mathrm{Al}$ show the existence of the $\alpha$-phase with decreasing percentage of $\gamma_{2}$. The $\gamma_{2}$-phase increases proportionally to the $\alpha$-phase due to an increase in aluminum percentage from 11 to $14 \%$, which is revealed in Fig. 3.

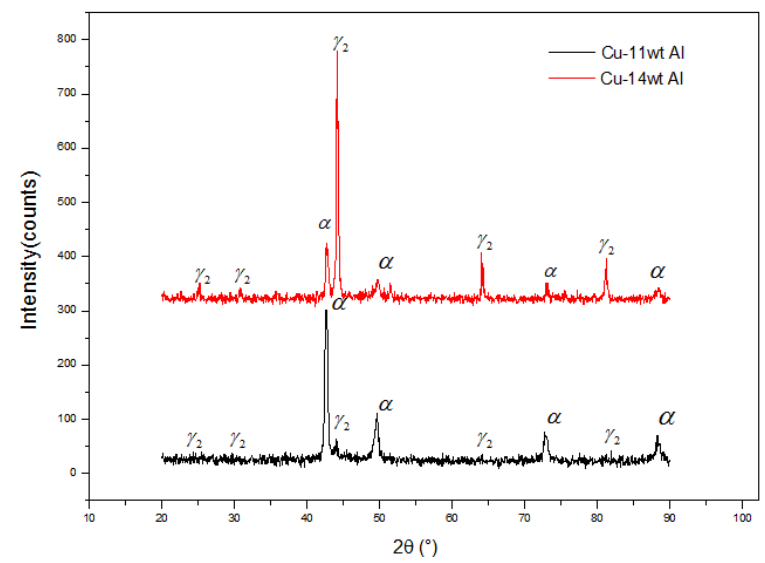

Fig. 3-X-ray diffraction patterns for $\mathrm{Cu}-11$ wt. $\% \mathrm{Al}$ and $\mathrm{Cu}-14$ wt. $\% \mathrm{Al}\left(1000{ }^{\circ} \mathrm{C}\right)$
X-ray diffraction patterns for samples with 18 wt. \% of $\mathrm{Al}$ show the $\gamma_{2}$-phase (see Fig. 4). This corresponds to what the phase diagram shows [13].

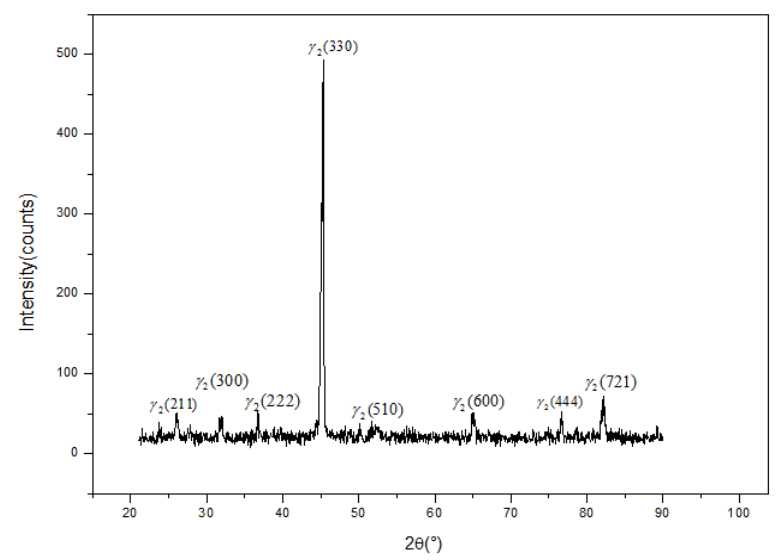

Fig. 4 - X-ray diffraction patterns for $\mathrm{Cu}-18$ wt. $\% \mathrm{Al}\left(800^{\circ} \mathrm{C}\right)$

\subsection{Granular Size}

X-ray diffraction spectra were used to determine the grain size of the samples. The size of the crystallites was calculated from the full width at half maximum (FWHM) of the peaks using the Scherrer formula [14]:

$$
L=\frac{k \lambda}{B \cos \theta},
$$

where $L, k, \lambda, B$ and $\theta$ represent, respectively, the crystallite size, Scherrer constant, X-ray wavelength, diffraction peak width, and Bragg angle.

It is noticed that whenever the aluminum concentration increases, the average diameter of granules increases consequently (Fig. 5), which corresponds to the clarification of linear shrinkage relation [15]:

$$
\frac{\Delta L}{L_{0}}=\left(\frac{K \gamma a^{3} D t}{k_{B} T d^{n}}\right)^{m},
$$

where $\Delta L / L_{0}$ is the linear shrinkage, $\gamma, a^{3}, D, k_{B}, T$ and $t$ represent, respectively, the surface energy, atomic volume, diffusion coefficient, Boltzmann constant, temperature and time, $K$ is a geometry-dependent constant, $n$ is typically close to 3 , and $m$ is generally in the range of 0.3 to 0.5 .

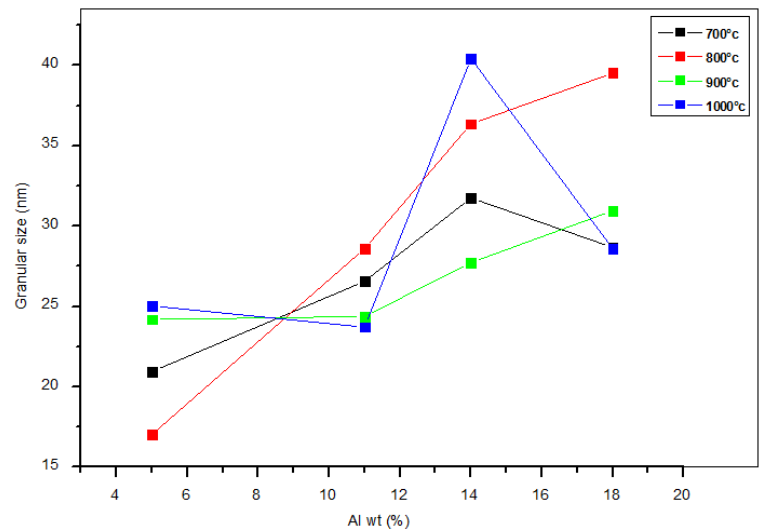

Fig. 5 - Granular size changes with aluminum concentration 
Using the solution of Fick's equation and extracting $D(x=0)$, then inserting it into relation (2), we can find

$$
\frac{\Delta L}{L_{0}}=\left(\frac{K \gamma a^{3} Q^{2}}{k_{B} T d^{n} \pi c^{2}}\right)^{m} .
$$

$Q$ and $c$ represent, respectively, aluminum concentration before and after sintering.

\subsection{Density}

To determine the density of the samples, we measured the size and mass of each sample using sensitive devices and then divided the size by mass. Fig. 6 shows changes in density with sintering temperature. In general, a slight change was observed in the increase in the density of samples with 5,11, 14 and 18 wt. \% of $\mathrm{Al}$, however, for the sample with 0 wt. \% of $\mathrm{Al}$, the change was clearer and more important than the change in other samples.

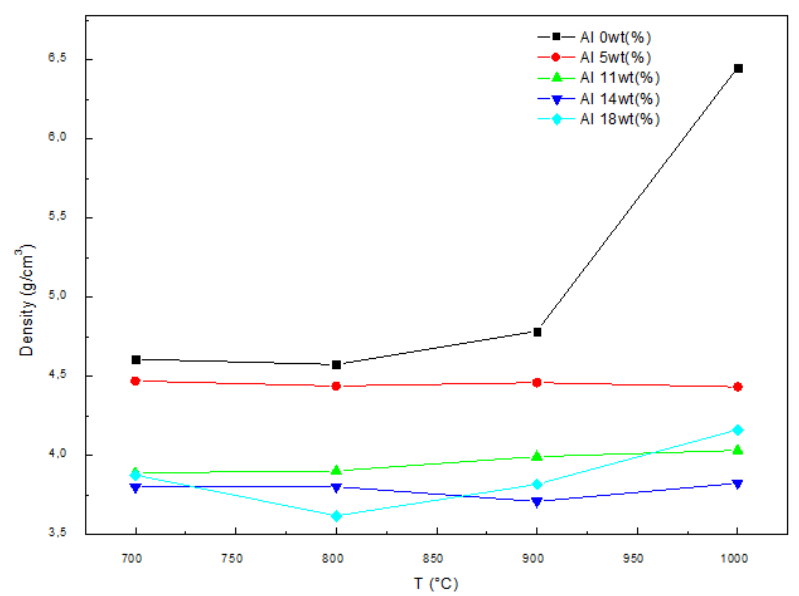

Fig. 6 - Density changes with sintering temperature

Fig. 7 shows changes in volumetric mass in terms of aluminum concentration. It is clear that whenever aluminum percentage increases, the volumetric mass of the samples decreases, which is consistent with the curves of volumetric mass change with aluminum concentration in references $[16,17]$.

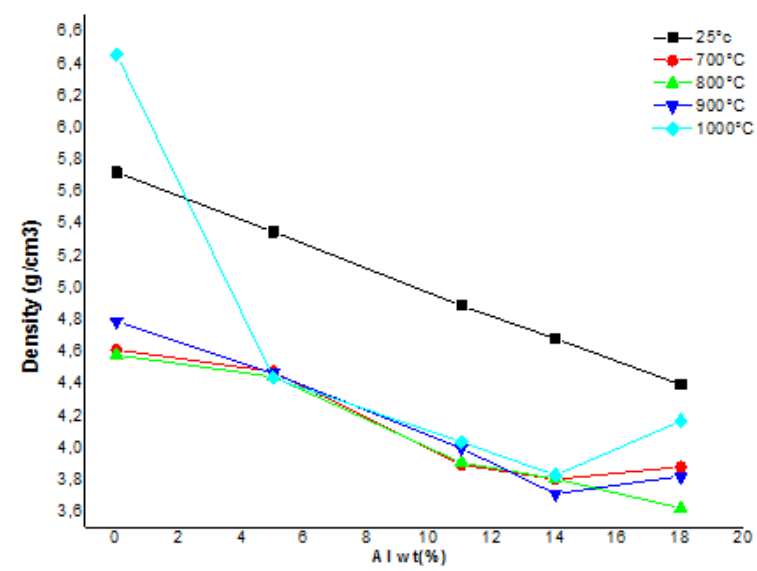

Fig. 7 - Density changes with aluminum concentration

\subsection{Hardness}

The Vickers hardness of untreated samples ranges from 46.7 to $69.8 \mathrm{~kg} / \mathrm{mm}^{2}$, but for treated samples, it is in the range from 52.3 to $698.8 \mathrm{~kg} / \mathrm{mm}^{2}$. By comparing the extreme values of the hardness of treated and untreated samples, we can conclude about the effectiveness of sintering temperature, at which the hardness increases tenfold from 69.8 to $698.8 \mathrm{~kg} / \mathrm{mm}^{2}$.

Fig. 8 shows changes in hardness with sintering temperature. We can notice that whenever the temperature increases, the hardness increases, this is due to the increased diffusion of aluminum with increasing temperature. We can see that the curves are arranged one above the other orderly, whenever the percentage of aluminum increases, the curve rises, i.e., whenever the percentage of aluminum increases, the hardness rises. We can also notice that high values of hardness are concentrated between 18 and 14 wt. \% of Al, particularly samples with 18 wt. \% of $\mathrm{Al}$, where the hardness is never below 370 and even reaches $700 \mathrm{~kg} / \mathrm{mm}^{2}$. Comparing this and the results of XRD patterns, it should be concluded that the samples of higher hardness are those having a higher percentage of the $\gamma_{2}$-phase.

Concerning samples of the $\alpha$-phase, the hardness reaches the extreme values of $116.5,160.5,148.2 \mathrm{~kg} / \mathrm{mm}^{2}$ in samples with 0,5 , and $11 \mathrm{wt} \%$ of $\mathrm{Al}$, respectively. In a previous study, it was found that the hardness of a sample with 5 wt. $\% \mathrm{Al}$ reached $170 \mathrm{~kg} / \mathrm{mm}^{2}$ [18].

With a closer scrutiny to Fig. 9, which represents changes in the size of granules with aluminum concentration at $1000{ }^{\circ} \mathrm{C}\left(1000{ }^{\circ} \mathrm{C}\right.$ is taken to have extreme values of hardness in this region), and if divide the aluminum concentration area by phases into two parts: the first part from 5 to 11 wt. $\% \mathrm{Al}$ (field of the $\alpha$-phase) and the second one from 14 to $18 \mathrm{wt} \% \mathrm{Al}$ (field of the $\gamma_{2}$-phase), we can notice in each field that whenever the granule size decreases, the hardness increases.

Taking the extreme value of hardness, which is equal to $698.8 \mathrm{~kg} / \mathrm{mm}^{2}$ for a sample with $18 \mathrm{wt}$ \% of $\mathrm{Al}$, the volumetric mass of this sample is $4.164 \mathrm{~g} / \mathrm{cm}^{3}$. However, at $14 \mathrm{wt} \%$ of $\mathrm{Al}$, the extreme hardness is $615.2 \mathrm{~kg} / \mathrm{mm}^{2}$ and the density is $3.826 \mathrm{~g} / \mathrm{cm}^{3}$. One can observe the only one increasing curve.

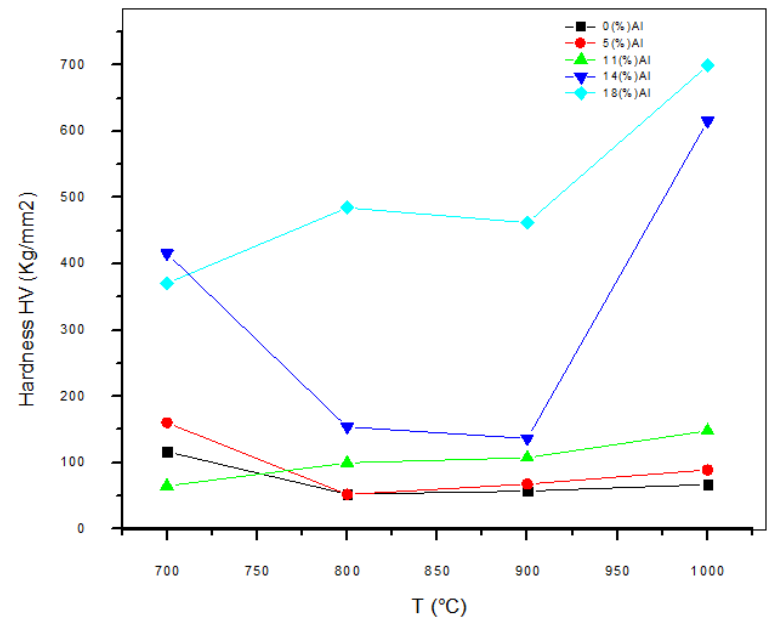

Fig. 8 - Hardness changes with sintering temperature 

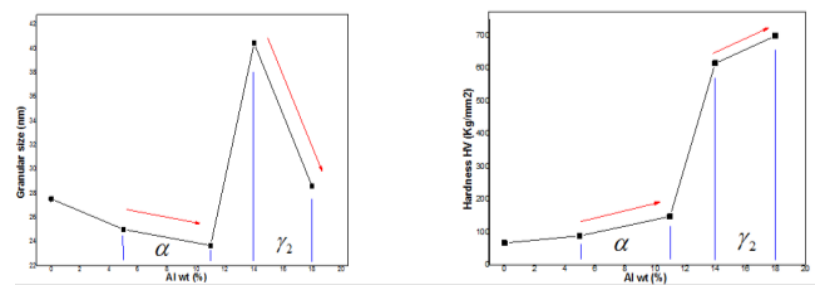

Fig. 10 - Hardness changes with granular size in the region of phase $\alpha$ and region of phase $\gamma_{2}$ of samples sintered at $1000{ }^{\circ} \mathrm{C}$

\section{CONCLUSIONS}

In this work, we have studied the influence of sintering temperature and aluminum concentration on hardness, microstructure and density of $\mathrm{Cu}-(5,11,14$, and 18 wt. \%) of Al. From the results we can conclude that for samples with $5 \mathrm{wt} . \% \mathrm{Al}$, the $\alpha$-phase is formed and increases with increasing temperature until it reaches a maximum of $900{ }^{\circ} \mathrm{C}$. The $\gamma_{2}$-phase increases at the expense of the $\alpha$-phase with increasing $\mathrm{Al}$ percentage from 11 to $14 \mathrm{wt} \% \mathrm{Al}$, and at $18 \mathrm{wt} . \% \mathrm{Al}, \gamma_{2}$ is the only phase. The sintering temperature increases the hardness, and samples with the $\gamma_{2}$-phase have the highest hardness. In the monophasic area, the hardness increases with decreasing granular size. We also noticed that as the volumetric mass decreases, the hardness decreases.

\title{
REFERENCES
}

1. T. Kayaba, Wear 5, 173 (1962).

2. T. Huseyin, Mater. Lett. 59 No 12, 1463 (2005).

3. X. Zhang, X. Ren, X. Hong, X. Gao, RSC Adv. 9, 34972 (2019).

4. X. Xiong, J. Chen, P. Yao, Wear 262, 1182 (2007).

5. P. Ramakrishnan, Advances in Powder Metallurgy (Woodhead Publishing Series in Metals and Surface Engineering: 2013).

6. C.A. Braun, M. Schumaker, J. Rice, et al, Eng. Mater. Technol. 138 No 1, 011003 (2016).

7. Y. Xiao, P. Yao, K. Fan, et al., Friction 6, 219 (2018).

8. D. Wilson, R. Roberts, J. Blyth, Powder Compaction (Chemical Engineering in the Pharmaceutical Industry: 2019).

9. P.K. Bardhan, S. Patra, G. Sutradhar, Mater. Sci. Appl. 1, 152 (2010).

10. S.S.M. Nor, M.M. Rahman, F. Tarlochan, B. Shahida, et al., J. Mater. Proc. Technol. 207, 118 (2008).

11. M.M. Rahman, N.H.M. Zabri, Proceedings of the $23 r d$ Scientific Conference of Microscopy Society Malaysia, SCMSM 2014, 4919153 (American Institute of Physics Inc.: 2015).

12. N. Ponweiser, C.L. Lengauer, K.W. Richter, Intermetallics 19, 1737 (2011).

13. L. Gong, L. Jian-Hua, W. Wen-Kui, et al., Chinese Phys. B 19, 096202 (2010).

14. C.S. Barret, T.B. Massalski, Structure of Metals (McGrawHill: New York: 1996).

15. D.W. Richerson, Modern Ceramic Engineering (New York: 1992).

16. J. Brillo, I. Egry, J. Westphaln, Int. J. Mater. Res. 99, 162 (2008).

17. Y. Plevachuk, V. Sklyarchuk, A. Yakymovych, et al., Metallur. Mater. Trans. A 39, 3040 (2008)

18. X.H. An, S. Qu, S.D. Wu, et al., J. Mat. Res. 26, 407 (2011).

\section{Вплив температури спікання та концентрації алюмінію на твердість, мікроструктуру та щільність мідно-алюмініевих сплавів}

\author{
D. Slimani ${ }^{1,2}$, A. Souigat ${ }^{1,3}$, R. Gheriani ${ }^{2}$, O. Bentouila ${ }^{3}$ \\ ${ }^{1}$ Ecole normale supérieure de Ouargla, 30000 Ouargla, Algeria \\ ${ }^{2}$ Lab. Rayonnement et Plasmas et Physique des Surfaces, Univ Ouargla, Fac. des Mathématiques et des Sciences \\ de la Matière, 30000 Ouargla, Algeria \\ ${ }^{3}$ Lab. Développement des Energies Nouvelles et Renouvelables en Zones Aride, Univ Ouargla, Fac. des \\ Mathématiques et des Sciences de la Matière, 30000 Ouargla, Algeria
}

\begin{abstract}
За останні десятиліття технологія порошкової металургії значно просунулася вперед і застосовуеться для виробництва спечених конструкційних компонентів з надзвичайно високою точністю розмірів та відмінною обробкою поверхні. Цей процес заснований на пресуванні суміші металевого порошку та спіканні в печі з використанням контрольованої температури та атмосфери. Дана технологія відповідае вимогам до структури мідних сплавів з кращими механічними властивостями при найменших витратах. Це спонукало нас вивчити вплив температури спікання та концентрації алюмінію на твердість, мікроструктуру та щільність мідно-алюмінієвих (Cu-Al) сплавів, отриманих за допомогою процесу пресування порошку. У роботі зразки сплаву $\mathrm{Cu}-\mathrm{Al}$ з 5, 11, 14 та 18 мас. \% $\mathrm{Al}$ отримували механічним легуванням порошків з подальшим спіканням під тиском $12,5 \mathrm{MПа} \mathrm{при} 700-1000{ }^{\circ} \mathrm{C}$ у вакуумі протягом 90 хв. Дослідження мікроструктури проводились методом рентгенівської дифракції. Проведені вимірювання щільності і твердості та встановлена їх залежність від розміру гранул та утворених фаз. Зразки фази $\gamma_{2}$ показали вищу твердість.
\end{abstract}

Ключові слова: Сплави $\mathrm{Cu}-\mathrm{Al}$, Дифракція рентгенівських променів, Твердість, Розмір гранул, Фаза $\gamma_{2}$. 